\title{
Molecular epidemiology of giardiasis among Orang Asli in Malaysia: application of the triosephosphate isomerase gene
}

\author{
Tengku Shahrul Anuar', Siti Nor Azreen², Fatmah Md Salleh² and Norhayati Moktar ${ }^{2 *}$
}

\begin{abstract}
Background: Giardia duodenalis is a flagellate parasite which has been considered the most common protozoa infecting human worldwide. Molecular characterization of $G$. duodenalis isolates have revealed the existence of eight groups (Assemblage $\mathrm{A}$ to $\mathrm{H}$ ) which differ in their host distribution. Assemblages $\mathrm{A}$ and $\mathrm{B}$ are found in humans and in many other mammals.

Methods: This cross-sectional study was conducted to identify assemblage's related risk factors of $G$. duodenalis among Orang Asli in Malaysia. Stool samples were collected from 611 individuals aged between 2 and 74 years old of whom 266 were males and 345 were females. Socioeconomic data were collected through a pre-tested questionnaire. All stool samples were processed with formalin-ether sedimentation and Wheatley's trichrome staining techniques for the primary identification of $G$. duodenalis. Molecular identification was carried out by the amplification of a triosephosphate isomerase gene using nested-PCR assay.
\end{abstract}

Results: Sixty-two samples (10.2\%) were identified as assemblage A and 36 (5.9\%) were assemblage B. Risk analysis based on the detected assemblages using univariate and logistic regression analyses identified subjects who have close contact with household pets i.e. dogs and cats $(\mathrm{OR}=2.60 ; 95 \% \mathrm{Cl}=1.42,4.78 ; P=0.002)$ was found to be significant predictor for assemblage $\mathrm{A}$. On the other hand, there were three significant risk factors caused by assemblage $\mathrm{B}$ : (i) children $\leq 15$ years old $(\mathrm{OR}=2.33 ; 95 \% \mathrm{Cl}=1.11,4.87 ; P=0.025)$, (ii) consuming raw vegetables $(\mathrm{OR}=2.82 ; 95 \% \mathrm{Cl}=1.27,6.26 ; P=0.011)$ and (iii) the presence of other family members infected with giardiasis $(\mathrm{OR}=6.31 ; 95 \% \mathrm{Cl}=2.99,13.31 ; P<0.001)$.

Conclusions: The present study highlighted that G. duodenalis infection among Orang Asli was caused by both assemblages with significant high prevalence of assemblage A. Therefore, taking precaution after having contact with household pets and their stool, screening and treating infected individuals, awareness on the importance of good health practices and washing vegetables are the practical intervention ways in preventing giardiasis in Orang Asli community.

Keywords: Giardia duodenalis, Assemblage, Risk factors, Orang Asli, Malaysia

\footnotetext{
*Correspondence: tsatab@lycos.com

${ }^{2}$ Department of Parasitology and Medical Entomology, Faculty of Medicine, Universiti Kebangsaan Malaysia, Jalan Raja Muda Abdul Aziz, 50300 Kuala Lumpur, Malaysia

Full list of author information is available at the end of the article
} reproduction in any medium, provided the original work is properly cited. The Creative Commons Public Domain Dedication waiver (http://creativecommons.org/publicdomain/zero/1.0/) applies to the data made available in this article, unless otherwise stated. 


\section{Background}

Giardia is a genus of intestinal flagellates that infects a wide range of vertebrate hosts. The genus currently comprises six species, namely Giardia agilis in amphibians, Giardia ardeae and Giardia psittaci in birds, Giardia microti and Giardia muris in rodents and Giardia duodenalis in mammals. These species are distinguished on the basis of the morphology and ultrastructure of their trophozoite [1]. Giardia duodenalis (syn. Giardia intestinalis and Giardia lamblia) is the only species within the genus Giardia that infects humans, although it is also found in other mammals including pets and livestock [2]. The infection has a global distribution, with an estimated $2.8 \times 10^{8}$ cases per year, represents the most common gastrointestinal parasitic infection of humans in developed countries [3]. In Asia, Africa and Latin America, about 200 million people have symptomatic giardiasis with some 500,000 new cases reported each year [4]. There are four characteristics of $G$. duodenalis that influence the epidemiology of infection: (i) the infective dose is about 10 to 100 cysts in humans; (ii) cysts are immediately infectious when excreted in stool and can be transmitted by human-to-human or animal-toanimal contact; (iii) cysts are remarkably stable and can survive for weeks to months in the environment and (iv) environmental contamination can lead to the contamination of drinking water and food $[5,6]$.

A considerable amount of data has shown that G. duodenalis should be considered a species complex whose members show little variation in their morphology yet can be assigned to at least eight distinct assemblages (A to $\mathrm{H}$ ) based on genetic analyses $[7,8]$. The analysis of more than a thousand human isolates from different geographical locations, examined by PCR amplification of DNA extracted directly from stool has demonstrated that in almost all cases, only G. duodenalis assemblages A and B are associated with human infections [5]. The prevalence of each assemblage varies considerably from country to country; assemblage B seems more common overall, but no strong conclusions can be drawn from current data. The remaining assemblages ( $C$ to $G$ ) are likely to be host specific, as assemblages $C$ and $D$ have been identified in dogs, cats, coyotes and wolves; assemblage $\mathrm{E}$ in cattle, sheep, goats, pigs, water buffaloes and muflons; assemblage $\mathrm{F}$ in cats and assemblage $\mathrm{G}$ in rats.

In Malaysia, giardiasis is an endemic disease and is associated with malnutrition among children in the rural areas resulting in stunting, wasting and vitamin A deficiency $[9,10]$. The prevalence of giardiasis varies between 0.2 to $20 \%$ [11-13]. Most of the epidemiological studies detected G. duodenalis on the basis of microscopic examination without employing molecular approach. Data on genotypes of G. duodenalis up to the assemblage level remains scarce. In a previous genotyping study using SSU rRNA locus, one specimen was identified as assemblage A in 42 specimens and the rest were assemblage B [14]. In a study on immunocompromised patients, assemblage A was identified in four of the microscopy-positive specimens using triosephosphate isomerase (tpi) gene [15]. Assemblage A was also isolated from environmental samples including recreational lake water and water bodies in a zoo [16,17]. In addition, genotyping study was conducted on animals and assemblages $\mathrm{A}$ and $\mathrm{E}$ were detected among goats [18]. Recent study conducted by Huey et al. [19] based on multilocus analysis revealed that $42 \%$ of the Orang Asli isolates belong to assemblage A and $45 \%$ belonged to assemblage $\mathrm{B}$. However, determining the association of potential risk factors caused by both assemblages were not conducted in the previous studies which limit our understanding on the dynamic transmissions and the source of $G$. duodenalis infection in this country. Thus, the present study was conducted to identify G. duodenalis assemblage and the risk factors based on tpi gene to attain better understanding of the genetic diversity and transmission of giardiasis. The tpi gene was chosen because of the high genetic heterogeneity displayed by Giardia species at this locus [20-22].

\section{Methods}

\section{Study area and design}

The cross-sectional study was conducted from June to December 2011 among 611 individuals living in eight villages from Negeri Sembilan, Perak and Pahang of Malaysia. Sample selection was achieved using a two-stage sampling method: (i) random selection of villages (ii) random selection of 10 to 15 households per village. All village entry has been approved by the Ministry of Rural and Regional Development of Malaysia. With an expected minimum prevalence of $G$. duodenalis in the study area was $20 \%$ [13], the $95 \%$ confidence interval and an absolute precision of 0.05 [23], the appropriate sample size for the study was estimated to be 246 subjects. Within each village, subjects over 2 years of age and those who provided consent to participate were included in this study. Exclusion criteria included children below 2 years old and refusal to participate.

\section{Structured questionnaire}

The rationale and procedures of the study were explained and an informed consent sheet was signed by the head of the household or a designated literate substitute. A trained research team interviewed each subject using a previously tested, structured questionnaire that sought information on the following groups of variables: (i) demographic data (i.e. age, gender and education level); (ii) socioeconomic background (i.e. occupation, household income and educational status); (iii) behavioural risks (i.e. personal hygiene such as hand washing and food consumption); (iv) environmental 
sanitation and characteristics of living condition (i.e. types of water supply, latrine system and sewage disposal system); (v) close contact with household pets (i.e. dogs or cats). This questionnaire was first designed in English and then translated and pretested in the Malay language, which is the national language for Malaysia and well understood by the subjects. For children, the questionnaire was completed by interviewing their parents or guardians who signed the informed consent. Subjects who participated in this study were honoured with a small token of appreciation.

\section{Stool samples collection}

Following the administration of the questionnaire, a $100 \mathrm{ml}$ wide mouth screw-capped container pre-labelled with the subject's name and code were distributed to all subjects for the collection of their stool sample the next day. Their ability to recognize their names was counterchecked. Each subject was instructed to scoop a thumb size stool sample using a provided scoop into the container. Then, the container was placed in a zip-locked plastic bag. Parents and guardians were instructed to monitor their children during the sample collection to ensure that they place their stool samples into the right containers. All study subjects were asked to provide sufficiently large stool sample (at least $10 \mathrm{~g}$ ) so that both microscopic techniques and the molecular method could be performed. This study had to rely on a single stool collection because of the limitation of resources and the cultural belief of the Orang Asli against giving away their stool samples.

\section{Parasitological examination}

Stool samples were processed in the designated area of work in the study village within a minimum of four hours after collection by experienced laboratory technicians. Approximately, $5 \mathrm{~g}$ of each stool sample were kept in a $15 \mathrm{ml}$ centrifuge tube containing $3 \mathrm{ml}$ Polyvinyl Alcohol (PVA). PVA-fixed samples were forwarded to the Parasitology Department of the Faculty of Medicine, Universiti Kebangsaan Malaysia. The samples were processed using the Wheatley's trichrome staining method. Briefly, the smear cover slips were stained as follows: (i) iodine alcohol (15 min); (ii) 70\% alcohol (10 min); (iii) Wheatley's trichrome stain (10 minutes); (iv) acid alcohol (3 s); (v) 95\% alcohol (5 min); (vi) absolute alcohol (5 min); (vii) Wintergreen oil (5 min) [24]. Each cover slip was mounted using Distrene, Plasticiser and Xylene (DPX) and examined under the light microscope at a magnification of $1,000 \times$. Additionally, another half of the samples were kept unpreserved and stored at $4^{\circ} \mathrm{C}$ upon arrival at the laboratory for further analysis by formalinether sedimentation and DNA extraction. Briefly, $2 \mathrm{~g}$ of stool sample were mixed with $7 \mathrm{ml}$ of formalin and $3 \mathrm{ml}$ of ether, centrifuged, stained with Lugol's iodine, and finally examined under light microscopy at a magnification of 400x [25]. Samples were considered microscopically positive if cysts and/or trophozoites were detected in at least one of the two techniques, and negative if negative in both the techniques. All microscopically-positive ( $\mathrm{n}=$ 110) samples were further characterized using molecular procedures.

\section{DNA extraction}

DNA was extracted directly from all stool samples using QIAamp Stool DNA extraction kit (Qiagen, Hilden, Germany) according to the manufacturer's instructions. Briefly, $0.2 \mathrm{~g}$ of stool was placed in a microcentrifuge tube, incubated at $70^{\circ} \mathrm{C}$ for 5 min with the cell lysis and disruption agent provided by the manufacturer. This was then subjected to homogenization and lysis procedure for complete cell lysis by using mechanical vortex (Silent Crusher S, Germany). The final DNA elution was prepared in $70 \mu \mathrm{l}$ of elution buffer. The concentration of extracted DNA was measured by a spectrophotometer (Eppendorf, Germany) at $260 \mathrm{~nm}$ and then the samples were stored at $-20^{\circ} \mathrm{C}$ until used.

\section{PCR amplification of the triosephosphate isomerase gene}

A partial sequence of tpi gene (530-bp) was amplified using nested-PCR protocol according to Sulaiman et al. [22]. Primary PCR was run using forward primer AL3543 (5' -AAA TIA TGC CTG CTC GTC G-3') and reverse primer AL3546 (5'-CAA ACC TTI TCC GCA AAC C-3'). For secondary PCR, forward primer AL3544 (5'-CCC TTC ATC GGI GGT AAC TT-3') and reverse primer AL3545 (5'-GTG GCC ACC ACI CCC GTG CC-3') were used. Primary and secondary PCRs were performed in a $50 \mu \mathrm{l}$ PCR mix comprising $0.2 \mu \mathrm{M}$ of each primer (Bio Basic Canada Inc). $1 \mathrm{U}$ of HotStarTaq ${ }^{\oplus}$ Plus DNA Polymerase (Qiagen, Hilden, Germany), $1 \times$ PCR buffer (Qiagen, Hilden, Germany), $200 \mu \mathrm{M}$ dNTP (Fermentas, Ontario, Canada), $1.5 \mathrm{mM} \mathrm{MgCl}_{2}$ (Qiagen, Hilden, Germany) and $0.2 \mathrm{mg} / \mathrm{ml}$ BSA (New England Biolabs, Ipswich, USA). $2 \mu$ of DNA template were used and the prepared master mix was incubated in the Eppendorf Pro-S thermal cycler (Hamburg, Germany) under the following conditions: initial hot start at $95^{\circ} \mathrm{C}$ for $5 \mathrm{~min}, 35$ amplification cycles at $94^{\circ} \mathrm{C}$ for $45 \mathrm{~s}, 50^{\circ} \mathrm{C}$ for $45 \mathrm{~s}\left(58^{\circ} \mathrm{C}\right.$ for secondary $\mathrm{PCR}$ ), $72^{\circ} \mathrm{C}$ for $60 \mathrm{~s}$ and a final extension at $72^{\circ} \mathrm{C}$ for $10 \mathrm{~min}$.

In addition, the first PCR product of the reaction described by Sulaiman et al. [22] underwent further amplification using a set of separate A [26] and B [27] assemblage-specific primers. Presence of mixed infection was detected by visualizing the occurrence of bands in the agarose gel at 332-bp for assemblage A amplified using primers AssAF (5'-CGC CGT ACA CCT GTC-3') 
and AssAR (5'-AGC AAT GAC AAC CTC CTT CC-3') and at 400-bp for assemblage $\mathrm{B}$ amplified using primers AssBF (5'-GTT GTT GTT GCT CCC TCC TTT-3') and AssBR (5' -CCG GCT CAT AGG CAA TTA CA-3'). The PCR reaction mix consisted of $0.2 \mu \mathrm{M}(0.4 \mu \mathrm{M}$ for assemblage B) of each primer (Bio Basic Canada Inc). $1.25 \mathrm{U}$ of HotStarTaq Plus DNA Polymerase (Qiagen, Hilden, Germany), $1 \times$ PCR buffer (Qiagen, Hilden, Germany), $200 \mu \mathrm{M}$ dNTP (Fermentas, Ontario, Canada), $1.5 \mathrm{mM} \mathrm{MgCl} 2$ (Qiagen, Hilden, Germany) and $0.1 \mathrm{mg} / \mathrm{ml}$ BSA (New England Biolabs, Ipswich, USA) to a final volume of $25 \mu \mathrm{l} .1 \mu \mathrm{l}$ of DNA template was added for assemblage $\mathrm{A}$ and $2 \mu \mathrm{l}$ was added for assemblage $\mathrm{B}$ for the PCR amplifications following the cycle parameter: initial hot start at $95^{\circ} \mathrm{C}$ for $5 \mathrm{~min}$, initial denaturation at $94^{\circ} \mathrm{C}$ for $10 \mathrm{~min}$ and 35 amplification cycles at $94^{\circ} \mathrm{C}$ for $45 \mathrm{~s}$, $64^{\circ} \mathrm{C}$ for $45 \mathrm{~s}\left(62^{\circ} \mathrm{C}\right.$ for secondary PCR $)$ and $72^{\circ} \mathrm{C}$ for $45 \mathrm{~s}$.

In all the PCR reactions, a Giardia-positive DNA sample and distilled water were used as a positive and negative control. The amplified products were analyzed by electrophoresis in $1.5 \%$ agarose gel (Vivantis) and stained with GelRed (0.1 $\mu \mathrm{l} / \mathrm{mL}$ : Biotium).

\section{DNA sequencing and phylogenetic analysis}

The positive amplicons were then purified using the SolGent $^{\text {tw }}$ kit (South Korea) according to the manufacturer's instruction. All purified amplicons were sequenced in both directions using the same primer sets as in the respective PCR assay with an ABI 3730XL sequencer (Applied Biosystems, USA). The chromatograms and sequences generated from this study were viewed and assembled using the BioEdit Sequence Alignment Editor Programme (www. mbio.ncsu.edu/bioedit/bioedit.html). Preliminary similarity comparison of the consensus sequence with the sequences in GenBank database was made using Basic Local Alignment Search Tool (BLAST) (www.ncbi.nlm.nih.gov/ BLAST). The isolate sequences were genotyped into assemblage using multiple alignments implemented by ClustalW [28] with previously defined reference sequences retrieved from GenBank database. The following reference sequences were used in the analysis: AF069556 (assemblage A), AF069557 (assemblage A), L02120 (assemblage A), U57897 (assemblage A), AF069560 (assemblage B), AF069561 (assemblage B), L02116 (assemblage B), AF069563 (assemblage C) and AF069559 (assemblage E).

Phylogenetic analysis was performed in MEGA 5 (www. megasoftware.net) using neighbour-joining algorithms with evolutionary distances calculated by Kimura-2-parameter method [29] and 1000 bootstrap value. Sequences of G. ardeae (AF069564) and G. muris (AF069565) were used as the out group since the construction on an unrooted tree showed them to be the most divergent members under analysis.

\section{Data analysis}

Data was entered in a Microsoft Access and was crosschecked by technical staff to ensure that they were entered correctly. Statistical analysis was performed using the SPSS software (Statistical Package for the Social Sciences) program for Windows version 20 (SPSS, Chicago, IL, USA). Prevalence of G. duodenalis assemblages A and $B$ were determined on the basis of microscopic examination and the molecular method. Only those subjects with complete questionnaire data and whose stool samples were processed via formalin-ether sedimentation, Wheatley's trichrome staining and nestedPCR assay were included in the final analyses.

For descriptive analysis, percentage rates were used to describe the characteristics of the studied population, including the prevalence of $G$. duodenalis assemblage A and assemblage B. A Chi-square test $\left(X^{2}\right)$ was used to test the association between the variables. In the univariate analysis, the dependent variable was prevalence of G. duodenalis assemblage $\mathrm{A}$ and assemblage $\mathrm{B}$, while the independent variables were demographic and socioeconomic factors, behavioural risks, environmental sanitation, living condition characteristics and close contact with household pets. All univariate models were used to assess potential associations between $G$. duodenalis assemblages A and B infections and the characteristics of the potential associated factor. The level of statistical significance was set at $P<0.05$ and for each statistically significant factor, an odds ratio (OR) and $95 \%$ confidence interval (CI) were computed for both univariate and multivariate logistic regression analysis. All factors that were significant in the univariate model were included in a logistic multivariate analysis to determine which factors could be dropped from the multivariable model.

\section{Ethical considerations and treatment}

The study protocol (Reference Number: UKM 1.5.3.5/ 244/FF-165-2011) was reviewed and approved by the Ethics Committee of Universiti Kebangsaan Malaysia Medical Centre (UKMMC) and permission for field work was obtained from the Ministry of Rural and Regional Development of Malaysia before starting the study. Village meetings were held and village authorities and villagers were handed detailed explanations about the aims, procedures, potential risks and benefit from the study. During the meetings, they were also informed that their identities and personal particulars would be kept strictly confidential and they could withdraw from the study at any point of time without citing reasons for doing so. If they agreed to participate, their consent was obtained in written form (signature or thumbprint for those who were illiterate) or parents were approached for consent on behalf of their children. At the end of the study, each subject confirmed with G. duodenalis infection by PCR was treated 
with metronidazole according to the Ministry of Health Malaysia, free of charge.

\section{Results}

Characteristics of the study population

Single stool samples were randomly collected from a total of 611 subjects. With regards to the age groups, $277(45.3 \%)$ were less than 15 years while $334(54.7 \%)$ were 15 years old or above $(\geq 15)$, with a median age of 18 years [interquartile range (IQR) 9-34]. Subjects who participated in this study comprised 266 (43.5\%) males and 345 (56.5\%) females.

More than half $(68 \%)$ of the parents have low level of education i.e., less than 6 years of formal education. The majority of the parents did odd jobs such as selling forest products without any stable income. Some were daily wage earners working in rubber or palm oil plantations, unskilled labourers in factories or construction sites. Therefore, $51.6 \%$ of the households belonged to people who earned less than RM500 per month ( $\leq$ US\$156.02), the poverty income threshold in Malaysia (Department of Statistics Malaysia, 1997. Profile of Orang Asli in Peninsular Malaysia, Kuala Lumpur) which is inadequate to maintain a good living standard. Although $61.9 \%$ if the houses have provision of basic infrastructure such as treated water supply and $71.4 \%$ have pour flush toilet, at least $38.1 \%$ are still using untreated water originating from a nearby river for their domestic needs and 28.6\% still defecate indiscriminately in the river or bush. More than half of the households (55.8\%) kept dogs and cats as their pets. Most of these pets are left to roam freely. The villagers have very close contact with the dogs and cats. Occasionally, these pets also slept, defecated indoors and accompanied the villagers into the forest to harvest forest products.

\section{Prevalence of Giardia duodenalis assemblages A and B infections}

Table 1 shows that $10.2 \%(62 / 611)$ and $5.9 \%(36 / 611)$ of the subjects were infected with $G$. duodenalis assemblage $\mathrm{A}$ and assemblage $\mathrm{B}$, respectively. The prevalence of G. duodenalis assemblages A and B infections were not significantly associated with gender. However, the prevalence of G. duodenalis assemblage B infection was significantly higher in the younger age group of less than 15 years $(P=0.021)$.

\section{Associated factors for Giardia duodenalis assemblages A and $B$ infections}

The association of G. dudoenalis assemblages A and B infections and sociodemographic characteristics are shown in Table 2. The results showed that drinking untreated water $(\mathrm{OR}=1.72 ; 95 \% \mathrm{CI}=1.01,2.91 ; P=0.042)$ and close contact with household pets $(\mathrm{OR}=2.72 ; 95 \% \mathrm{CI}=1.48$,
Table 1 Distribution of Giardia duodenalis assemblage A and assemblage $B$ by age and gender among Orang Asli in Malaysia $(n=611)$

\begin{tabular}{|c|c|c|c|c|c|}
\hline \multirow[t]{2}{*}{ Variables } & \multirow{2}{*}{$\begin{array}{c}\text { No. } \\
\text { examined }\end{array}$} & \multicolumn{2}{|c|}{ Assemblage $\mathrm{A}$} & \multicolumn{2}{|c|}{ Assemblage B } \\
\hline & & $\begin{array}{c}\text { No. } \\
\text { infected }\end{array}$ & $\begin{array}{c}\% \\
\text { Infected }\end{array}$ & $\begin{array}{c}\text { No. } \\
\text { infected }\end{array}$ & $\begin{array}{c}\% \\
\text { Infected }\end{array}$ \\
\hline \multicolumn{6}{|l|}{$\begin{array}{l}\text { Age groups } \\
\text { (years) }\end{array}$} \\
\hline$<15$ & 277 & 28 & 10.1 & 23 & 8.3 \\
\hline$\geq 15$ & 334 & 34 & 10.1 & 13 & 3.9 \\
\hline \multicolumn{6}{|l|}{ Gender } \\
\hline Male & 266 & 32 & 12.0 & 17 & 6.4 \\
\hline Female & 345 & 30 & 8.7 & 19 & 5.5 \\
\hline Total & 611 & 62 & 10.2 & 36 & 5.9 \\
\hline
\end{tabular}

4.98; $P=0.001$ ) were significantly associated with $G$. duodenalis assemblage A infection. On the other hand, $G$. duodenalis assemblage B infection was associated with five factors which include children less than 15 years old $(\mathrm{OR}=2.23 ; 95 \% \mathrm{CI}=1.11,4.50 ; P=0.021)$, consuming raw vegetables $(\mathrm{OR}=3.13 ; 95 \% \mathrm{CI}=1.48,6.61 ; P=0.002)$, eating fresh fruits $(\mathrm{OR}=3.47 ; 95 \% \mathrm{CI}=11.50,1.51 ; P=$ $0.030)$, non working mother $(\mathrm{OR}=3.07 ; 95 \% \mathrm{CI}=1.105$, 9.04; $P=0.033$ ) and the presence of other family members infected with giardiasis $(\mathrm{OR}=7.75 ; 95 \% \mathrm{CI}=3.76,15.94$; $P<0.001)$.

\section{Aetiological factors associated with Giardia duodenalis assemblage $A$ and assemblage $B$ infections}

Logistic regression analysis confirmed that individuals who have close contact with household pets i.e., dogs and cats were 2.6 times $(95 \% \mathrm{CI}=1.42,4.78 ; P=0.002)$ more likely to be infected with $G$. duodenalis assemblage A as compared to those who do not keep dogs and cats as their pets. In addition, children less than 15 years old (OR = 2.33; $95 \% \mathrm{CI}=1.11,4.87 ; P=0.025)$, those being a consumer of raw vegetables $(\mathrm{OR}=2.82 ; 95 \% \mathrm{CI}=1.27,46.26$; $P=0.011)$ and presence of other family members infected with giardiasis $(\mathrm{OR}=6.31 ; 95 \% \mathrm{CI}=2.99,13.31 ; P<0.001)$ were more likely to be infected with $G$. duodenalis assemblage B (Table 3).

\section{Molecular characterization of Giardia duodenalis isolate}

Out of 110 microscopically-positive samples, 98 (89.1\%) were successfully amplified based on analysis targeting tpi gene using nested-PCR assay. Sixty-two of the isolates were classified assemblage $\mathrm{A}$, whereas 36 isolates were identified as assemblage $\mathrm{B}$. The neighbour-joining tree placed four representative sequences [AF069556 (assemblage A), AF069557 (assemblage A), L02120 (assemblage A) and U57897 (assemblage A)] in one cluster with high bootstrap support. Phylogenetic analysis confirmed 
Table 2 Potential risk factors associated with Giardia duodenalis assemblages A and B infections among Orang Asli (univariate analysis, $\mathrm{n}=611$ )

\begin{tabular}{|c|c|c|c|c|c|c|c|c|}
\hline \multirow[b]{2}{*}{ Variables } & \multicolumn{4}{|c|}{ Assemblage A } & \multicolumn{4}{|c|}{ Assemblage B } \\
\hline & $\begin{array}{c}\text { No. } \\
\text { examined }\end{array}$ & $\%$ Infected & OR $(95 \% \mathrm{Cl})$ & $P$-value & $\begin{array}{c}\text { No. } \\
\text { examined }\end{array}$ & $\%$ Infected & OR $(95 \% \mathrm{Cl})$ & $P$-value \\
\hline \multicolumn{9}{|l|}{ Age (years) } \\
\hline$<15$ & 277 & 10.1 & $0.99(0.759,1.68)$ & 0.977 & 277 & 8.3 & $2.23(1.11,4.50)$ & $0.021^{\mathrm{a}}$ \\
\hline$\geq 15$ & 334 & 10.2 & 1 & & 334 & 3.9 & 1 & \\
\hline \multicolumn{9}{|l|}{ Gender } \\
\hline Male & 266 & 12.0 & $1.44(0.85,2.43)$ & 0.176 & 266 & 6.4 & $1.17(0.60,2.30)$ & 0.646 \\
\hline Female & 345 & 8.7 & 1 & & 345 & 5.5 & 1 & \\
\hline \multicolumn{9}{|l|}{ Drinking untreated water } \\
\hline Yes & 233 & 13.3 & $1.72(1.01,2.91)$ & $0.042^{\mathrm{a}}$ & 233 & 8.2 & $1.89(0.96,3.71)$ & 0.062 \\
\hline No & 378 & 8.2 & 1 & & 378 & 4.5 & 1 & \\
\hline \multicolumn{9}{|c|}{ Bathing and washing in the river } \\
\hline Yes & 175 & 7.4 & $0.63(0.34,1.20)$ & 0.159 & 175 & 8.0 & $1.64(0.82,3.28)$ & 0.161 \\
\hline No & 436 & 11.2 & 1 & & 436 & 5.0 & 1 & \\
\hline \multicolumn{9}{|c|}{$\begin{array}{l}\text { Not washing hands after playing } \\
\text { with soil or gardening }\end{array}$} \\
\hline Yes & 215 & 10.7 & $1.10(0.64,1.89)$ & 0.740 & 215 & 10.7 & $1.10(0.64,1.89)$ & 0.740 \\
\hline No & 396 & 9.8 & 1 & & 396 & 9.8 & 1 & \\
\hline \multicolumn{9}{|c|}{ Close contact with household pets } \\
\hline Yes & 341 & 13.8 & $2.72(1.48,4.98)$ & $0.001^{\mathrm{a}}$ & 341 & 7.0 & $1.63(0.80,3.32)$ & 0.176 \\
\hline \multirow[t]{2}{*}{ No } & 270 & 5.6 & 1 & & 270 & 4.4 & 1 & \\
\hline & \multicolumn{4}{|c|}{ Assemblage $\mathrm{A}$} & \multicolumn{4}{|c|}{ Assemblage B } \\
\hline Variables & $\begin{array}{c}\text { No. } \\
\text { examined }\end{array}$ & $\%$ Infected & OR $(95 \% \mathrm{Cl})$ & $P$-value & $\begin{array}{c}\text { No. } \\
\text { examined }\end{array}$ & $\%$ Infected & OR $(95 \% \mathrm{Cl})$ & $P$-value \\
\hline \multicolumn{9}{|l|}{ Indiscriminate defecation } \\
\hline Yes & 205 & 10.7 & $1.10(0.64,1.91)$ & 0.734 & 205 & 7.3 & $1.45(0.73,2.87)$ & 0.288 \\
\hline No & 406 & 9.9 & 1 & & 406 & 5.2 & 1 & \\
\hline \multicolumn{9}{|l|}{ Sewage disposal } \\
\hline Outdoor & 264 & 10.2 & $1.01(0.60,1.73)$ & 0.954 & 264 & 7.6 & $1.70(0.86,3.34)$ & 0.123 \\
\hline Common drainage & 347 & 10.1 & 1 & & 347 & 4.6 & 1 & \\
\hline \multicolumn{9}{|l|}{ Eating with hands } \\
\hline Yes & 390 & 9.2 & $0.76(0.45,1.30)$ & 0.319 & 390 & 6.7 & $1.51(0.71,3.19)$ & 0.280 \\
\hline No & 221 & 11.8 & 1 & & 221 & 4.5 & 1 & \\
\hline \multicolumn{9}{|l|}{ Consuming raw vegetables } \\
\hline Yes & 287 & 11.8 & $1.42(0.84,2.41)$ & 0.190 & 287 & 9.1 & $3.13(1.48,6.61)$ & $0.002^{\mathrm{a}}$ \\
\hline No & 324 & 8.6 & 1 & & 324 & 3.1 & 1 & \\
\hline \multicolumn{9}{|l|}{ Eating fresh fruits } \\
\hline Yes & 470 & 10.4 & $1.15(0.60,2.18)$ & 0.678 & 470 & 7.0 & $3.47(1.05,11.50)$ & $0.030^{\mathrm{a}}$ \\
\hline No & 141 & 9.2 & 1 & & 141 & 2.1 & 1 & \\
\hline \multicolumn{9}{|l|}{ Father's education } \\
\hline Non-educated (<6 yrs) & 253 & 9.9 & $1.02(0.48,2.15)$ & 0.965 & 253 & 4.3 & $0.98(0.33,2.90)$ & 0.973 \\
\hline Educated (>6 yrs) & 113 & 9.7 & 1 & & 113 & 4.4 & 1 & \\
\hline
\end{tabular}


Table 2 Potential risk factors associated with Giardia duodenalis assemblages A and B infections among Orang Asli (univariate analysis, $\mathbf{n}=\mathbf{6 1 1}$ ) (Continued)

\begin{tabular}{|c|c|c|c|c|c|c|c|c|}
\hline \multicolumn{9}{|l|}{ Mother's education } \\
\hline Non-educated (<6 yrs) & 250 & 10.8 & $1.44(0.65,3.17)$ & 0.363 & 250 & 4.0 & $0.76(0.27,2.16)$ & 0.610 \\
\hline Educated (>6 yrs) & 116 & 7.8 & 1 & & 116 & 5.2 & 1 & \\
\hline \multicolumn{9}{|l|}{ Non working mother } \\
\hline Yes & 157 & 10.8 & $1.21(0.61,2.42)$ & 0.581 & 157 & 7.0 & $3.07(1.05,9.04)$ & $0.033^{a}$ \\
\hline \multirow[t]{2}{*}{ No } & 209 & 9.1 & 1 & & 209 & 2.4 & 1 & \\
\hline & \multicolumn{4}{|c|}{ Assemblage A } & \multicolumn{4}{|c|}{ Assemblage B } \\
\hline Variables & $\begin{array}{l}\text { No. } \\
\text { examined }\end{array}$ & $\%$ Infected & OR $(95 \% \mathrm{Cl})$ & $P$-value & $\begin{array}{l}\text { No. } \\
\text { examined }\end{array}$ & $\%$ Infected & OR $(95 \% \mathrm{Cl})$ & $P$-value \\
\hline \multicolumn{9}{|l|}{ Household members } \\
\hline$\geq 8$ & 216 & 11.1 & $1.17(0.68,2.02)$ & 0.560 & 216 & 6.5 & $1.18(0.59,2.35)$ & 0.647 \\
\hline$<8$ & 395 & 9.6 & 1 & & 395 & 5.6 & 1 & \\
\hline \multicolumn{9}{|l|}{ Household monthly income ${ }^{b}$} \\
\hline$\leq \mathrm{RM} 500$ & 315 & 10.2 & $1.00(0.59,1.70)$ & 0.992 & 315 & 7.3 & $1.72(0.85,3.45)$ & 0.127 \\
\hline$>\mathrm{RM} 500$ & 296 & 10.1 & 1 & & 296 & 4.4 & 1 & \\
\hline \multicolumn{9}{|c|}{$\begin{array}{l}\text { Other family members infected } \\
\text { with giardiasis }\end{array}$} \\
\hline Yes & 142 & 14.1 & $1.67(0.94,2.95)$ & 0.076 & 142 & 16.9 & $7.75(3.76,15.94)$ & $<0.001^{a}$ \\
\hline No & 469 & 9.0 & 1 & & 469 & 2.6 & 1 & \\
\hline
\end{tabular}

$\mathrm{Cl}=$ Confidence interval.

$\mathrm{OR}=$ Odds ratio, Reference group marked as $\mathrm{OR}=1$.

${ }^{\text {a }}$ Significant association $(P<0.05)$.

${ }^{\mathrm{b}} \mathrm{RM}=$ Malaysian Ringgit; $\leq$ US\$ $156.02\left(10^{\text {th }}\right.$ December 2013).

the monophyletic group of assemblage B (bootstrap = 100\%) (Figure 1).

\section{Discussion}

Molecular tools have been recently used to characterize the epidemiology of human giardiasis. Although isolates of Giardia duodenalis from human and various animals are morphologically similar, distinct host-adapted genotypes have been demonstrated within G. duodenalis [22,30]. Human giardiasis is cause by two distinct genetic groups of $G$. duodenalis known as assemblages A and B. Both assemblages are found associated with human infection globally

Table 3 Odds ratio (OR) of the aetiological factors for Giardia duodenalis assemblages A and B infections among Orang Asli

\begin{tabular}{|c|c|c|c|}
\hline Variables & OR & $95 \% \mathrm{Cl}$ & $P$-value \\
\hline \multicolumn{4}{|l|}{ Assemblage A } \\
\hline Close contact with household pets & 2.60 & $1.42,4.78$ & 0.002 \\
\hline \multicolumn{4}{|l|}{ Assemblage B } \\
\hline Children ( $\leq 15$ years) & 2.33 & $1.11,4.87$ & 0.025 \\
\hline Consuming raw vegetables & 2.82 & $1.27,6.26$ & 0.011 \\
\hline $\begin{array}{l}\text { Presence of other family members } \\
\text { infected with } G \text {. duodenalis }\end{array}$ & 6.31 & $2.99,13.31$ & $<0.001$ \\
\hline
\end{tabular}

$\mathrm{Cl}=$ Confidence interval. and have also been detected in various animals. In this study, the results showed that all G. duodenalis infections in Orang Asli are due to assemblage A and assemblage B. This confirmed the results of a several local studies performed elsewhere $[14,19]$.

At present, various molecular methods are available to distinguish these assemblages, mainly by nested-PCR followed by DNA sequencing or restriction fragment length polymorphism (RFLP), or by real-time PCR [31]. The majority of these assays are based on the amplification of a gene fragment with primers that bind to DNA sequences that are conserved in the two assemblages (or conserved in all G. duodenalis assemblages or in Giardia species). In the course of this study, triosephosphate isomerase (tpi) gene was specially chosen because of the high genetic heterogeneity displayed by Giardia species at this locus, as depicted by Thompson and Monis [7]. A recent local study done by Huey et al. [19] reported that the tpi gene achieved the highest percentage of amplicons produced (70\%), followed by glutamate dehydrogenase $(g d h)(45 \%)$ and beta-giardin (bg) (33\%). Similar occurrences were also reported in previous studies [32,33]. Furthermore, according to the results of Sulaiman et al. [22], the tpi gene is a good phylogenetic marker for analysis of the molecular evolutionary and taxanomic relationship of G. duodenalis. 


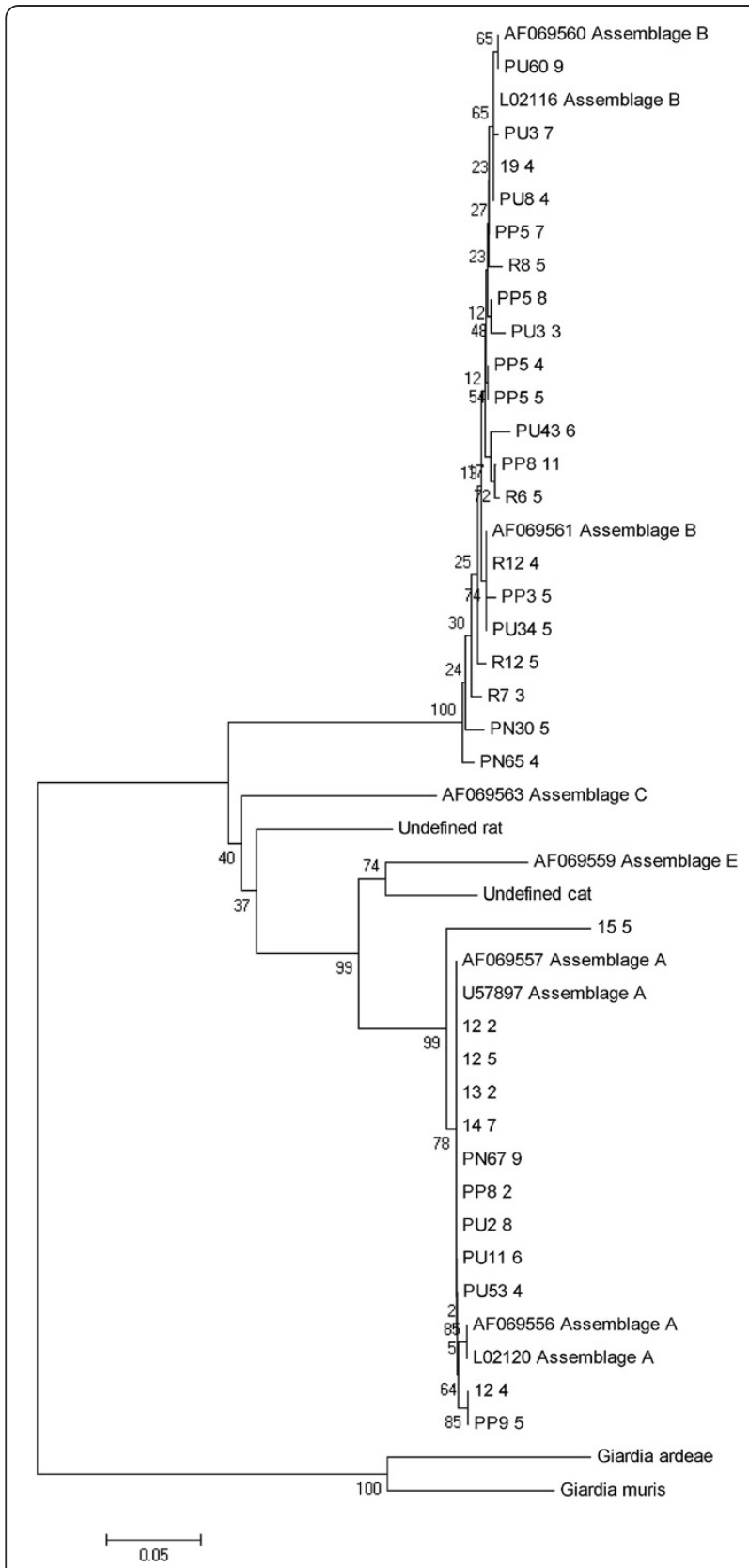

Figure 1 Phylogenetic tree of the Giardia duodenalis assemblages constructed by neighbour-joining analysis, based on the nucleotide sequences of triosephosphate isomerase retrieved from this study compared with reference sequences of known assemblages from GenBank. Bootstrap values obtained from 1000 replicates are indicated on branches in percentage.

The distribution of $G$. duodenalis assemblages varied in different geographical areas. In the present study, sequences analysis of the 98 samples recovered from Orang Asli revealed 10.2\% (62/611) G. duodenalis assemblage A and $5.9 \%(36 / 611)$ assemblage $B$, which were differs from previous local studies carried out by Mohammed Mahdy et al. [34] and Huey et al. [19]. In their studies, they found out that majority of these communities were infected with assemblage B. A high prevalence rate of assemblage A in the present study was in agreement with the results of Hussein et al. [35] which observed that assemblage A was more prevalent in eight stool samples. In Egypt, Helmy et al. [36] reported 75\% assemblage A and 19.5\% assemblage B among 41 patients. Another study conducted in Mexico had also shown that all 26 homogeneous isolates from humans belonged to assemblage A [37]. Similarly, all seven human isolates in Korea characterized at the SSU rRNA locus were from assemblage A [38]. Souza et al. [39] indicated that infections with assemblage A (78.4\%) was more prevalent in Brazil, whereby Homan and Mank [40] observed that assemblage A was more prevalent in patients between 8 to 60 years of age in the Netherlands.

In contrast, a high prevalence rate of assemblage $B$ was reported by Hatam-Nahavandi et al. [41]. Likewise, Tungtrongchitr et al. [42] in Thailand proved that assemblage B (51\%) was more common than assemblage A (8\%). Breathnach et al. [43] observed 73\% of assemblage B and $24 \%$ assemblage A in 199 human stool samples in the southwest of London. In Nepal, Singh et al. [44] indicated that infection with assemblage B (74\%) was more prevalent than assemblage A (20\%) in patients older than 12 years of age. Curiously, Volotao et al. [45] did not find G. duodenalis assemblage B infecting humans in the city of Rio de Janeiro, Brazil. Results from each of these studies are not strictly comparable since amplifications were done on different G. duodenalis genes. Differences of G. duodenalis assemblage among the studied populations could be due to different modes of transmission in each area, comprising human-to-human, foodborne, waterborne or zoonotic transmissions.

Results of this study indicate a non-significant difference in the prevalence of G. duodenalis assemblages A and $B$ infections between genders. Similar findings were observed by Gelanew et al. [46] and Anthony et al. [47] which found no significant difference between assemblage's distribution and gender in Ethiopia and the Philippines. On the other hand, Mohammed Mahdy et al. [48] demonstrated that females were at two-fold higher risk of acquiring giardiasis caused by assemblage B compared to males.

Interestingly, this study showed that children age less than 15 years were at higher risk of being infected with assemblage B. This finding was in agreement with Mohammed Mahdy et al. [48] and Sadek et al. [49] that addressed this age group as a high risk group for giardiasis. This result was also consistent with worldwide reports including Malaysia suggesting that giardiasis is one of the major health problems among population of younger age groups $[13,34,50]$. The strong association between assemblage $\mathrm{B}$ infection and younger age group 
raises a question of whether G. duodenalis assemblages show age-specific pattern. Compared to previous studies carried out in Ethiopia [49], Philippines [50] and Australia [51], it seems that children are susceptible to both assemblages with variability in predominance from one country to country. The susceptibility could be attributed to the practicing improper personal hygiene. Lacking in effective immunity has also been postulated to explain this agespecific pattern.

Foodborne transmission of giardiasis was suggested in 1920s [52,53] and anecdotal evidence from outbreaks frequently implicated food handlers and contaminated vegetables or fruits [54]. Consuming raw vegetables was found to be a significant risk factor for G. duodenalis assemblage $\mathrm{B}$ in the present study. The most common vegetables consumed in Orang Asli were tapioca shoots, wild fern shoots and locally planted leaves. It was believed that this association was due to eating these vegetables with contaminated hands or hands that were insufficiently washed. Contaminated hands have been implicated to play a major role in the faecal-oral transmission of the communicable faecal-oral transmitted diseases in developing countries [55,56]. Other sources of food contamination include washing salad vegetables in water containing infectious cysts, the use of excrement (night soil) for fertilizer, contaminated irrigation water in the cultivation of food crops and the dissemination of cysts from stool to food by filth flies $[57,58]$. Vegetables can be surface contaminated with Giardia cysts $[59,60]$, although it was often unclear whether cyst contamination was due to cultivation practices, contaminated water, insects or other animal vectors, or following handling by individuals with cyst-contaminated hands. Raw wastewater used as fertilizer but not treated wastewater or fresh water was responsible for contaminating coriander, mint, carrots and radish in a study conducted in Marrakech, Morocco [61].

The host distribution of G. duodenalis assemblage B was predominantly human and to a much lesser extent $\operatorname{dog}$ and wildlife. The present finding suggests that humans are the major source of assemblage $B$ and it indicates the possibility of infected family members as the source of infection and direct transmission occurring within the household. It has also been demonstrated in Bangkok where human-to-human transmission of assemblage B was found among humans in temple communities [62]. Likewise, Cooper et al. [63] suggested that humanto-human transmission was much more important than animal-to-human transmission. In their study, they found that assemblage B frequently co-existed within families and co-infected subjects. Under such circumstances, children may be at constant risk of infection and this can be observed in the present study where the prevalence of $G$. duodenalis assemblage $\mathrm{B}$ was high in children younger than 15 years old. Furthermore, the prevalence of G. duodenalis assemblage $\mathrm{B}$ which indicates an anthroponotic transmission cycle has been seen in other countries in Asia [64] and the Indian subcontinent [65].

Zoonotic transmission of G. duodenalis is still under debate and despite increasing knowledge of the molecular identification of Giardia from different host species; the zoonotic potential of $G$. duodenalis is not clear $[66,67]$. However, the present epidemiological study once again highlighted close contact with household pets was 2.6 times more likely to become infected with $G$. duodenalis assemblage A. We considered household pets as dogs and cats that were kept contained in residence area (house and/or yard) for at least $12 \mathrm{~h}$ a day and allowed in the streets part of the day, either alone or accompanied by their owners. The role of dogs and cats as a definitive $G$. duodenalis host has been widely studied and recognized as being a public health problem, especially in developing countries and communities that were socioeconomically disadvantages as the one used in this study. In these communities, poor levels of hygiene and overcrowding, together with a lack of veterinary attention and zoonotic awareness, exacerbates the risk of giardiasis transmission [68]. Further evidence for zoonotic transmission was supported by the recovery of genetically similar isolates of Giardia in dogs and humans living within the same household, although it would appear that the risk of doghuman transmission was low.

In a recent report from Germany, it was found that of 60 Giardia positive samples collected from dogs in urban areas, $60 \%$ were infected with zoonotic Giardia from assemblage A, $12 \%$ with dog specific assemblages $C$ and D and the remaining 28\% harboured mixed infections [69]. Few studies have also been undertaken in cats but Vasilopulos et al. [70] examined 250 cats from Mississippi and Alabama and of 17 positive for Giardia, six infected with assemblage $\mathrm{A}$ and 11 with assemblage $\mathrm{F}$ (the cat genotype). Based on these findings, we believe that there are two transmission cycles in dogs; (i) the normal cycles between dogs which involves transmission of G. duodenalis cysts that belong to assemblages $\mathrm{C}$ or $\mathrm{D}$ and (ii) the other cycler includes cross transmission of Giardia from humans belonging to assemblage A [71] that grow in dog intestine. If this is true as the evidence supports, then dogs are G. duodenalis reservoir and transmit cysts in at least two ways which are from dog-to-dog and from humans-to-dogs and perhaps from dogs-to-humans.

It is interesting to note that mixed infections with $G$. duodenalis assemblages $\mathrm{A}$ and $\mathrm{B}$ were not detected in the current study. Similarly, Bertrand et al. [72] also did not found any mixed infections in their study among patients in France. However, the occurrence of mixed infections has been reported in molecular-based surveys performed in Australia [46], Italy [73], India [74] and 
United Kingdom [75]. The percentage of mixed infections ranged from 2 to $21 \%$ and was higher in less economically developed countries. Mixed infections can happen when a host ingests Giardia cysts of different genetic profiles or subsequent infection of an infected host by genetically different Giardia cysts. This was especially common in areas where giardiasis was endemic $[8,76,77]$.

The present study however has several limitations. Firstly, direct amplification of cysts DNA from stool samples help to sole important questions such as presence of mixed infections, association between assemblages and host (pathogenicity) and selection for irrelevant genotypes during cultivation $[22,78,79]$. But using directly stool for DNA amplification cause to decrease the yield of DNA extracted that can be improved by apply a more effective approach. In addition, there are many PCR inhibitors (i.e. lipids, haemoglobin, bile salts and polysaccharides from mucus, bacteria and food degradation product) which can affect the result of amplification. For this reason, some extraction and amplification methods have been improved to develop more sensitive assays to identify gene. In some studies, specific DNA was detected at all target concentrations, demonstrating that QIAamp DNA kit extraction method could effectively remove PCR inhibitory substances $[80,81]$. Secondly, molecular techniques based on PCR in combination with techniques such as RFLP have been successfully used for differentiation of $G$. duodenalis up to sub-assemblages $[79,82]$. The G. duodenalis assemblage A isolates have been further grouped into sub-assemblages I and II, whereby the assemblage $B$ isolates have been divided into sub-assemblages III and IV $[83,84]$. This, together with our results showed that it is important to combine different genotyping methods to get a clearer view of the assemblage of a Giardia isolate since different methods can group isolates into different assemblages and the resolution of sub-assemblages is dependent on the selected method.

\section{Conclusions}

In conclusion, determination of the G. duodenalis assemblage is a useful way to understand the dynamic transmission of Giardia infection in Orang Asli. In the base of our findings, an anthroponotic origin of the infection route is suggested and underscored the fact that human are the main source of infection for assemblage B while close contact with domestic animals played a major role in the transmission for assemblage A. Because of the possibility of zoonotic transmission and the potential of household pets for hosting the parasite suggested by some researchers, further studies with a variety species of animal stool samples are recommended. Further studies using additional, more highly variable loci will provide more definitive evidence of both anthroponotic and zoonotic transmission in this community.

\section{Competing interests}

The authors hereby declare that they have no competing interests.

\section{Authors' contributions}

TSA was involved in all phases of the study, including study design, data collection, data analysis and write up of the manuscript; NM supervised the study, and revised the manuscript; NM was involved in the statistical analysis of data; FMS and SNA were involved in the collection and laboratory examination of samples. All authors read and approved the final manuscript. TSA and NM are the guarantors of the paper

\section{Acknowledgements}

The authors gratefully acknowledge the Ministry of Rural and Regional Development Malaysia for granting us permission to conduct this research. We also thank all the participants from Parit Gong village, Pasu village, Pian village, Bagan Balak village, Sungai Banun village, Desa Damai village, Sungai Raba village, and Pengkalan Permai village for their commitment and contribution in providing their stool samples. This work was supported in part by the UKMMC Fundamental Research Grant (FF-165-2011) and Special Research University Grant (UKM-GUP-2011-316) from Universiti Kebangsaan Malaysia.

\section{Author details}

${ }^{1}$ Department of Medical Laboratory Technology, Faculty of Health Sciences, Universiti Teknologi MARA, Puncak Alam Campus, 42300 Selangor, Malaysia. ${ }^{2}$ Department of Parasitology and Medical Entomology, Faculty of Medicine, Universiti Kebangsaan Malaysia, Jalan Raja Muda Abdul Aziz, 50300 Kuala Lumpur, Malaysia.

Received: 10 December 2013 Accepted: 5 February 2014

Published: 12 February 2014

\section{References}

1. Adam RDA: The Giardia lamblia genome. Int J Parasitol 2001, 30:475-484.

2. Adam RDA: Biology of Giardia lamblia. Clin Microbiol Rev 2001, 14:447-475.

3. Lane S, Lloyd D: Current trends in research into the waterborne parasite Giardia. Crit Rev Microbiol 2002, 28:123-147.

4. WHO: The world health report 1996: Fighting disease, fostering development. Geneva, Switzerland: World Health Organization; 1996.

5. Caccio SM, Thompson RC, McLauchlin J, Smith HV: Unravelling Cryptosporidium and Giardia epidemiology. Trends Parasitol 2005, 21:430-437.

6. Smith HV, Caccio SM, Tait A, McLauchlin J, Thompson RC: Tools for investigating the environmental transmission of Cryptosporidium and Giardia infections in humans. Trends Parasitol 2006, 22:160-167.

7. Thompson RCA, Monis PT: Variation in Giardia: implication for taxanomy and epidemiology. Adv Parasitol 2004, 58:69-137.

8. Caccio SM, Ryan U: Molecular epidemiology of giardiasis. Mol Biochem Parasitol 2008, 160:75-80.

9. Al-Mekhlafi HM, Azlin M, Nor Aini U, Shaik A, Sa'iah A, Fatmah MS, Ismail MG, Ahmad Firdaus MS, Aisah MY, Rozlida AR, Norhayati M: Giardiasis is a predictor of childhood malnutrition in Orang Asli children in Malaysia. Trans R Soc Trop Med Hyg 2005, 99:686-691.

10. Al-Mekhlafi HM, Surin J, Sallam AA, Abdullah AW, Mahdy MAK: Giardiasis and poor vitamin A status among aboriginal school children in rural Malaysia. Am J Trop Med Hyg 2010, 83:523-527.

11. Norhayati M, Penggabean M, Oothuman P, Fatmah MS: Prevalence and some risk factors of Giardia duodenalis infection in a rural community in Malaysia. Southeast Asian J Trop Med Public Health 1998, 29:735-738.

12. Lim YAL, Ahmad RA, Smith HV: Current status and future trends in Cryptosporidium and Giardia epidemiology in Malaysia. $J$ Water Health 2008, 6:239-254

13. Anuar TS, Al-Mekhlafi HM, Ghani MK, Osman E, Yasin AM, Nordin A, Azreen SN, Salleh FM, Ghazali N, Bernadus M, Moktar N: Giardiasis among different tribes of Orang Asli in Malaysia: highlighting the presence of other family members infected with Giardia intestinalis as a main risk factor. Int J Parasitol 2012, 42:871-880. 
14. Mahdy MAK, Surin J, Mohd-Adnan A, Wan KL, Lim YAL: Molecular characterization of Giardia duodenalis isolated from Semai Pahang Orang Asli (Peninsular Malaysia aborigines). Parasitology 2009, 136:1237-1241.

15. Lim YAL, labal A, Surin J, Sim BL, Jex AR, Nolan MJ, Smith HV, Gasser RB: First genetic classification of Cryptosporidium and Giardia from HIV/AIDS patients in Malaysia. Infect Genet Evol 2011, 11:968-974.

16. Lim YAL, Lai MM, Mahdy MAK, Mat Naim HR, Smith HV: Molecular detection of Giardia contamination in wáter bodies in a zoo. Environ Res 2009, 109:857-859.

17. Lim YAL, Ramasame SD, Mahdy MAK, Sulaiman WY, Smith HV: Detection and molecular characterization of Giardia isolated from recreational lake wáter in Malaysia. Parasitol Res 2009, 106:289-291.

18. Lim YAL, Mahdy MAK, Tan TK, Goh XT, Jex AR, Nolan MJ, Sharma RS, Gasser RB: First molecular characterization of Giardia duodenalis from goats in Malaysia. Mol Cell Probes 2013, 27:28-31.

19. Huey CS, Mahdy MAK, Al-Mekhlafi HM, Nasr NA, Lim YAL, Mahmud R, Surin J: Multilocus genotyping of Giardia duodenalis in Malaysia. Infect Genet Evol 2013, 17:269-276.

20. Baruch AC, Isaac-Renton J, Adam RD: The molecular epidemiology of Giardia lamblia: a sequence-based approach. J Infect Dis 1996, 174:233-236.

21. Monis PT, Andrews RH, Mayrhofer G, Ey PL: Molecular systematics of the parasitic protozoan Giardia intestinalis. Mol Biol Evol 1999, 16:1135-1144.

22. Sulaiman IM, Fayer R, Bern C, Gilman RH, Trout JM, Schantz PM, Das P, LI $A A$, Xiao L: Triosephosphate isomerase gene characterization and potential zoonotic transmission of Giardia duodenalis. Emerg Infect Dis 2003, 9:1444-1452

23. Lwanga SK, Lemeshow S: Sample size determination in health studies: a practical manual. Geneva: World Health Organization; 1991.

24. Salleh FM, Anuar TS, Yasin AM, Moktar N: Wintergreen oil: a novel method in Wheatley's trichrome staining technique. J Microbiol Methods 2012, 91:174-178

25. Fleck SL, Moody AH: Diagnostic technique in medical parasitology $11^{\text {th }}$ edition. Cambridge: Cambridge U.P; 1993.

26. Geurden T, Geldhof $P$, Levecke B, Martens C, Berkvens D, Casaert S, Vercruysse J, Claerebout E: Mixed Giardia duodenalis assemblage A and E infections in Alves. Int J Parasitol 2007, 38:259-264.

27. Geurden T, Levecke B, Caccio SM, Visser A, De Grote G, Casaert S, Vercruysse J, Claerebout E: Multilocus genotyping of Cryptosporidium and Giardia in non-outbreak related cases of diarrhoea in human patients in Belgium. Parasitology 2009, 136:1161-1168.

28. Thompson JD, Higgins DG, Gibson TJ: CLUSTAL W: improving the sensitivity of progressive multiple sequence alignment through sequence weighting, position-specific gap penalties and weight matrix choice. Nucleic Acids Res 1994, 22:4673-4680.

29. Kimura M: A simple method for estimating evolutionary rates of base substitutions through comparative studies of nucleotide sequences. J Mol Evol 1980, 16:111-120.

30. Mclntyre L, Hoang L, Ong CSL, Lee P, Isaac-Renton JL: Evaluation of molecular techniques to biotype Giardia duodenalis collected during an outbreak. J Parasitol 2000, 86:172-177.

31. Feng $Y$, Xiao L: Zoonotic potential and molecular epidemiology of Giardia species and giardiasis. Clin Microbiol Rev 2011, 24:110-140.

32. Lalle M, Bruschi F, Castagna B, Campa M, Pozio E, Caccio SM: High genetic polymorphism among Giardia duodenalis isolates from Sahrawi children. Trans R Soc Trop Med Hyg 2009, 103:834-838.

33. David EB, Coradi ST, Oliveira-Sequeira TCG, Ribolla PEM, Katagiri $S$, Guimaraes S: Diagnosis of Giardia infections by PCR-based methods in children of an endemic area. J Venom Anim Toxins 2011, 17:209-215.

34. Mohammed Mahdy AK, Johari S, Lim YAL, Wan KL, Al-Mekhlafi HMS: Risk factors for endemic giardiasis-highlighting the posible association of contaminated water and food. Trans R Soc Trop Med Hyg 2008, 102:465-470

35. Hussein A, Yamaguchi T, Nakamoto K, Iseki M, Tokoro M: Multiplesubgenotype infections of Giardia intestinalis detected in Palestinian clinical cases using a subcloning approach. Parasitol Int 2009, 58:258-262.

36. Helmy MM, Abdel-Fattah HS, Rashed L: Real-time PCR/RFLP assay to detect Giardia intestinalis genotypes in human isolates with diarrhoea in Egypt. J Parasitol 2009, 95:1000-1004.

37. Cedillo-Rivera R, Darby JM, Enciso-Moreno JA, Ortega-Pierres G, Ey PL: Genetic homogeneity of axenic isolates of Giardia intestinalis derived from acute and chronically infected individuals in Mexico. Parasitol Res 2003, 90:119-123.
38. Yong TS, Park SJ, Hwang UW, Yang HW, Lee KW, Min DY, Rim HJ, Wang Y, Zheng F: Genotyping of Giardia lamblia isolates from humans in China and Korea using ribosomal DNA sequences. J Parasitol 2000, 86:887-891.

39. Souza SLP, Gennari SM, Richtzenhain LJ, Pena HFJ, Funada MR, Cortez A Gregori F, Soares RM: Molecular identification of Giardia duodenalis isolates from humans, dogs, cats and cattle from the state of Sao Paulo, Brazil by sequence analysis of fragments of glutamate dehydrogenase (gdh) coding gene. Vet Parasitol 2007, 149:258-264.

40. Homan WL, Mank TG: Human giardiasis: genotype like differences in clinical symptomatology. Int J Parasitol 2001, 31:822-826.

41. Hatam-Nahavandi K, Fallah E, Asgharzadeh M, Mirsamadi N, Mahdavipour B: Glutamate dehydrogenase and triose-phosphate isomerase coding genes for detection and genetic characterization of Giardia lamblia in human feces by PCR and PCR-RFLP. Turk J Med Sci 2011, 41:283-289.

42. Tungtrongchitr A, Sookrung N, Indrawattana N, Kwangsi S, Ongrotchanaku J, Cjaicumpa W: Giardia intestinalis in Thailand: identification of genotypes. J Health Pop Nutr 2010, 28:42-52.

43. Breathnach AS, McHugh TD, Butcher PD: Prevalence and clinical correlations of genetic subtypes of Giardia lamblia in an urban setting. Epidemiol Infect 2010, 138:1459-1467.

44. Singh A, Janaki L, Petri WA, Houpt ER: Giardia intestinalis assemblages A and B infections in Nepal. Am J Trop Med Hyg 2009, 81:538-539.

45. Volotao AC, Costa-Macedo LM, Haddad FS, Brandao A, Peralta JM, Fernandes $\mathrm{O}$ : Genotyping of Giardia duodenalis from human and animal samples from Brazil using beta-giardin gene: a phylogenetic analysis. Acta Trop 2007, 102:10-19.

46. Gelanew T, Lalle M, Hailu A, Pozio E, Caccio SM: Molecular characterization of human isolates of Giardia duodenalis from Ethiopia. Acta Trop 2007, 102:92-99.

47. Anthony JD, Yason L, Rivera WL: Genotyping of Giardia duodenalis isolates among residents of slum area in Manila, Philippines. Parasitol Res 2007, 101:681-687.

48. Mohammed Mahdy AK, Surin J, Wan KL, Mohd-Adnan A, Al-Mekhlafi MS, Lim YAL: Giardia intestinalis genotypes: risk factors and correlation with clinical symptoms. Acta Trop 2009, 112:67-70.

49. Sadek GS, El-Settawy MA, Nasr SA: Genotypic characterization of Giardia duodenalis in children in Menoufiya and Sharkiya governorates, Egypt. Life SC J 2013, 10:4006-4015.

50. Lim YAL, Ahmad RA, Osman A: Prevalence of Giardia and Cryptosporidium infection in a Temuan (aborigine) village in Malaysia. Trans $R$ Soc Trop Med Hyg 1997, 91:505-506.

51. Read C, Walters J, Robertson ID, Thompson RC: Correlation between genotype of Giardia duodenalis and diarrhoea. Int J Parasitol 2002, 32:229-231

52. Musgrave WE: Flagellate infestations and infections. J Am Med Assoc 1922, 79:2219-2220

53. Lyon BBV, Swalm WA: Giardiasis: its frequency, recognition and certain clinical factors. Am J Med Sci 1925, 170:348-364

54. Casemore DP: Foodborne protozoal infection. Lancet 1990, 336:1427-1432.

55. Velema J, Van-Wijnen G, Bult P, Van-Naerssen T, Jota S: Typhoid fever in Ujung Padang, Indonesia: high-risk groups and high-risk behaviours. Trop Med Int Health 1997, 2:1088-1094.

56. Hussein-Gasem M, Dolmans W, Keuter M, Djokomoeljanto R: Poor food hygiene and housing risk factors for typhoid fever in Semarang, Indonesia. Trop Med Int Health 2001, 6:484-490.

57. Gupta SR, Rao CK, Biswas H, Krishnaswami AK, Wattal BL, Raghavan NGS: Role of the housefly in the transmission of intestinal parasitic cysts/ova. Indian J Med Res 1972, 60:1120-1125.

58. Graczyk TK, Grimes BH, Knight R, Da Silva AJ, Pieniazek NJ, Veal DA: Detection of Cryptosporidium parvum and Giardia lamblia carried by synanthropic flies by combined fluorescentin situ hybridization and a monoclonal antibody. Am J Trop Med Hyg 2003, 68:228-232

59. Mastrandrea G, Micarelli A: Search for parasites in vegetables from the local markets in the city of Rome. Arch Ital Sci Med Trop Parasitol 1968, 49:55-59.

60. Robertson $L$, Gjerde B: Occurence of parasites on fruits and vegetables in Norway. J Food Prot 2001, 64:1793-1798.

61. Amahmid O, Asmama S, Bouhoum K: The effect of waste water reuse in irrigation on the contamination level of food crops by Giardia cysts and Ascaris eggs. Int J Food Microbiol 1999, 49:19-26.

62. Traub RJ, Inpankaew T, Reid SA, Sutthikornchai C, Sukthana Y, Robertson ID, Thompson RCA: Transmission cycles of Giardia duodenalis in dogs and 
human in temple communities in Bangkok-A critical evaluation of its prevalence using three diagnostic tests in the field in the absence of a gold standard. Acta Trop 2009, 111:125-132.

63. Cooper MA, Sterling CR, Gilman RH, Cama V, Ortega Y, Adam RD: Molecular analysis of household transmission of Giardia lamblia in a region of high endemicity in Peru. J Infect Dis 2010, 202:1713-1721.

64. Yason JA, Rivera WL: Genotyping of Giardia duodenalis isolates among residents of slum area in Manila, Philippines. Parasitol Res 2007, 10:681-687.

65. Haque R, Roy S, Kabir M, Stroup SE, Mondal D, Houpt ER: Giardia assemblage $A$ infection and diarrhoea in Bangladesh. J Infect Dis 2005, 192:2171-2173.

66. Monis PT, Thompson RCA: Cryptosporidium and Giardia-zoonosis: fact or fiction? Inf Gen Evol 2003, 3:233-244.

67. Hunter PR, Thompson RCA: The zoonotic transmission of Giardia and Cryptosporidium. Int J Parasitol 2005, 35:1-10.

68. Traub RJ, Roberson ID, Irwin P, Mencke N, Thompson RC: The role of dogs in transission of gastrointestinal parasites in a remote tea-growing community in Northeastern India. Am J Trop Med Hyg 2002, 67:539-545.

69. Leonhard S, Pfister K, Beelitz P, Wielinga C, Thompson RCA: The molecular characterization of Giardia from dogs in Southern Germany. Vet Parasitol 2007, 150:33-38

70. Vasilopulos RJ, Rickard LG, Mackin AJ, Pharr GT, Huston CL: Genotypic analysis of Giardia duodenalis in domestic cats. J Vet Intern Med 2007, 21:352-355

71. Van Keulen H, Macechko IT, Wade S, Shaaf S, Wallis PM, Erlandsen SL: Presence of human Giardia in domestic, farm and wild animals, and environmental samples suggest a zoonotic potential of giardiasis. Vet Parasitol 2002, 108:97-107.

72. Bertrand I, Albertini L, Schwartzbrod J: Comparison of two target genes for detection and genotyping of Giardia lamblia in human feces by PCR and PCR-restriction fragmenth length polymorphism. J Clin Microbiol 2005, 43:5940-5944.

73. Hopkins RM, Meloni BP, Groth DM, Wetherall JD, Reynoldson JA, Thompson RC: Ribosomal RNA sequencing reveals differences between the genotypes of Giardia isolates recoverd from humans and dogs living in the same locality. J Parasitol 1997, 83:44-51.

74. Traub RJ, Monis P, Robertson I, Irwin P, Mencke N, Thompson RCA: Epidemiology and molecular evidence support the zoonotic transmission of Giardia among humans and dogs living in the same community. Parasitology 2004, 128:53-62.

75. Lalle M, Pozio E, Capelli G, Bruschi F, Crotti D, Caccio SM: Genetic heterogeneity at the $\beta$-giardin locus among human and animal isolates of Giardia duodenalis and identification of potentially zoonotic sub-genotypes. Int J Parasitol 2005, 35:207-213.

76. Sprong H, Caccio SM, Van der Giessen JW: Identification of zoonotic genotypes of Giardia duodenalis. PLoS Negl Trop Dis 2009, 3:e558

77. Lebbad M, Petersson I, Karlsson L, Botero-Kleiven S, Anderson JO, Svenungsson B, Svard SG: Multilocus genotyping of human Giardia isolates suggests limited zoonotic transmission and association between assemblage B and flatulance in children. PLOS Negl Trop Dis 2011, 5:e1262.

78. Homan WL, Gilsing M, Bentala H, Limper L, Van Knapen F: Characterization of Giardia duodenalis by polymerase chain-reaction fingerprinting. Parasitol Res 1998, 84:707-714.

79. Amar CFL, Dear PH, McLauchlin J: Detection and genotyping by real-time PCR-RFLP analyses of Giardia duodenalis from human feces. J Med Microbiol 2003, 52:681-683.

80. Machiels BM, Ruers T, Lindhout M, Hardy K, Hlavaty T, Bang DD: New protocol for DNA extraction of stool. Biotechniques 2000, 28:286-290

81. Abbaszadegan MR, Velayati A, Tavasoli A, Dadkhah E: Rapid DNA extraction protocol from stool, suitable for molecular genetic diagnosis of colon cancer. IBJ 2007, 11:203-208

82. McGlade TR, Robertson ID, Elliott AD, Thompson RCA: High prevalence of Giardia detected in cats by PCR. Vet Parasitol 2003, 110:197-205.
83. Siripattanapipong S, Leelayoova S, Mungthin M, Thompson RCA, Boontanom P, Saksirisampant W, Tan-ariya P: Clonal diversity of the glutamate dehydrogenase gene in Giardia duodenalis from Thai isolates: evidence of genetic exchange or mixed infection? BMC Microbiol 2011, 11:206.

84. Sarkari B, Ashraf Mansori A, Hatam GR, Motazedian MH, Asgari Q, Mohammad Pour I: Genotyping of Giardia lamblia isolates from human in Southern Iran. Trop Biomed 2012, 29:366-371.

doi:10.1186/1471-2334-14-78

Cite this article as: Anuar et al:: Molecular epidemiology of giardiasis among Orang Asli in Malaysia: application of the triosephosphate isomerase gene. BMC Infectious Diseases 2014 14:78.

\section{Submit your next manuscript to BioMed Central and take full advantage of:}

- Convenient online submission

- Thorough peer review

- No space constraints or color figure charges

- Immediate publication on acceptance

- Inclusion in PubMed, CAS, Scopus and Google Scholar

- Research which is freely available for redistribution

Submit your manuscript at www.biomedcentral.com/submit
C) BioMed Central 